\title{
Factors Influencing ASEAN and International Students of Higher Education Programs in Thailand
}

\author{
Aweewan Mangmeechai ${ }^{1}$ \& Ittisak Jirapornvaree ${ }^{1}$ \\ ${ }^{1}$ International College, Nationa Institute of Development Administration, Bangkok, Thailand \\ Correspondence: Aweewan Mangmeechai, International College, Nationa Institute of Development \\ Administration, Bangkok, Thailand. Tel: 66-2727-3552. E-mail: aweewan.m@nida.ac.th
}

Received: August 6, 2019

Accepted: August 17, $2019 \quad$ Online Published: August 302019

doi:10.5539/ass.v15n9p67

URL: https://doi.org/10.5539/ass.v15n9p67

\begin{abstract}
This study aims to understand the factors affecting graduate study choices of ASEAN and international students in Thailand. Quantitative and qualitative methods were applied in this study. The result showed that majority of international students between 2013 - 2015 were Chinese while among the ASEAN, students from Myanmar, Cambodia, and Laos were the highest. Among 42 factors, the most influential factor was quality of teachers who influence the selection by international students and ASEAN students significantly at the 0.05 level. International students place an emphasis on politics and security, while ASEAN students focus on future career prospects after graduation. The development of Thailand's competitiveness as an education hub in ASEAN is also possible. Thailand has the knowledge that is needed to enhance developing countries. It is recognized internationally for agriculture, public health, and education.
\end{abstract}

Keywords: education hub, ASEAN community, international program, education policy, factor influencing

\section{Introduction}

Education also promotes innovation and technology that is fundamental to the economic development of the country.

The Association of Southeast Asian Nations, or ASEAN, was first established in 1967 with aims and purposes to promote active collaboration and mutual assistance on matters of common interest in the economic, social, cultural, agriculture and industries, scientific and transport spheres and to raise the living standards of their peoples (Ministry of Foreign Affairs, 2014). Today, there are ten Member States of ASEAN. There are many countries that have set strategic plans aiming to develop an Association of Southeast Asian Nations (ASEAN) regional education hub. Singapore started their strategic plan in 2002, aiming to attract 150,000 international students by 2015 and to have 10 world-class educational institutes open in Singapore within 10 years. At the same time, Malaysia was planning to become a regional hub for international higher education and to have 100,000 international students by 2010. There were 13,617 international students studying in international programs in Thailand in 2014. Asian countries that are not ASEAN countries accounted for 7,006 students or $51.45 \mathrm{C}$, followed by ASEAN countries with 4,896 students or 37\%, and 697 students or $5.12 \%$ from European countries. In contrast, a group of countries with the lowest number of international students studying in Thailand was Australia, which had 52 students or $0.38 \%$. (Institute of International Education, 2016; UNESCO Institute of Statistics, 2016). Currently, educational competition, especially at the graduate level, is quite high. When the ASEAN Community opens, it will stimulate the competition in educational management for both domestic and international institutions. This will put pressure on higher education institutions in Thailand to enhance their higher educational quality. Thailand has continually developed higher education that is teaching international programs, especially at the graduate level in order to have higher education institutions adapt to meet the needs of ASEAN and international students. Students from different countries may have different expectations and selection criteria (Shah \& Laino, 2005; Shanka, Quintal, \& Taylor, 2005). There are a few research articles studied international programs in Business school and administration among local and international students in Thailand (Kashif \& Cheewakrakokbit, 2018; Pinkaeo \& Speece, 2008). No studies focusing on international program as an overall and comparing between ASEAN and international students. Thus, this study explored the factors affecting the selection of international programs at the graduate level at academic institutions in Thailand, in order to increase the competitiveness and prepare for improvements internationally to the academic 
institutions of Thailand.

\subsection{Academic Quality of Academic Institutions in Asian Countries and ASEAN Countries}

The rankings are often heavily criticized: because of their statistical inaccuracy, because of the measures chosen to represent academic quality, or because of their expected negative impact on the overall performance of universities. But recent research suggests that well designed organizational report cards can sometimes serve as effective instruments for public accountability (Dill \& Soo, 2005)

The overall situation about academic quality in Asian and ASEAN countries, ASEAN and international students transfer, the target countries, and factor influencing the selection of higher education institutions were discussed in this section.

From data unveiled in 2017, the top 100 universities in the world include 50 United States (US) universities, eight universities from the United Kingdom, six universities from Australia, four each from Switzerland, Canada, and Japan, three each from Germany, France, the Netherlands, and Sweden, two each from China, Belgium, and Israel, and one each from Denmark, Norway, Finland, Singapore, and Russia. Considering Asian countries and ASEAN countries, the country that was ranked in all three institutions and had the highest rank was Japan, followed by China and South Korea, respectively. For ASEAN countries, Singapore was ranked the highest by all three institutions, followed by Malaysia and Thailand, respectively (Academic Ranking of World Universities, 2016; Austin \& Shen, 2016). The data is shown in Table 1.

Table 1. The ranking of educational institutions in Asian and ASEAN community in 2017

\begin{tabular}{cccccc}
\hline Country & ARWU & ARWU & QS-WUR & THE-WUR \\
\cline { 2 - 5 } & Top 100 & Top 500 & Top 500 & Top 400 \\
\hline China & 1 & 52 & 82 & 41 \\
Hongkong & - & - & 7 & 6 \\
India & - & 1 & 23 & 3 \\
Indonesia & - & - & 11 & 1 \\
Japan & 4 & 12 & 74 & 37 \\
South Korea & - & 3 & 21 & 24 \\
Malaysia & - & - & 10 & 2 \\
Pakistan & - & - & 8 & - \\
Philippines & - & 1 & 3 & 2 \\
Singapore & 1 & - & 13 & 7 \\
Thailand & - & - & 5 & 2 \\
Vietnam & - & 3 & \\
\hline
\end{tabular}

\subsection{ASEAN and International Students transfer to Asia-Pacific Countries}

In the preparation of Thailand to enter the ASEAN Socio-Cultural Community, the Office of Higher Education Commission conducted a research study about the strategy needed to prepare for the ASEAN Community in 2015 by recognizing the impact of integration. It is an issue that the 15-year Higher Education Framework No. 2 (2008-2022) emphasizes as a direct factor that affects higher education management because the movement of people, students, and educational personnel will be more convenient and the liberalization of trade in education services will result in a shift of knowledge, language, and culture among the ASEAN countries. Higher education organizations are inevitably able to adapt themselves to merge into the ASEAN Community (Bureau of International Cooperation Strategy, 2016).

There were 13,617 foreign students who studied in higher education institutions in Thailand in 2014. The top three countries with the highest number of students studying in Thailand were China, Myanmar, and Cambodia, accounting for $17.69 \%, 6.30 \%$, and $4.60 \%$, respectively, as shown in Table 2 .

Table 2. The top 10 countries with the number of students who studied higher education in Thailand

\begin{tabular}{cccc}
\hline & International & & ASEAN \\
\hline Countries & Units & Countries & Units \\
\hline China & 4,544 & Myanmar & 1,620 \\
Myanmar & 1,620 & Cambodia & 1,182 \\
Cambodia & 1,182 & Laos & 793 \\
\hline
\end{tabular}




$\begin{array}{cccc}\text { Laos } & 793 & \text { Vietnam } & 748 \\ \text { Vietnam } & 748 & \text { Indonesia } & 274 \\ \text { United State } & 416 & \text { Philippines } & 148 \\ \text { South Korea } & 377 & \text { Malaysia } & 100 \\ \text { India } & 313 & \text { Timor-Leste } & 74 \\ \text { Bhutan } & 309 & \text { Singapore } & 30 \\ \text { Bangladesh } & 289 & \text { Brunei } & 1 \\ \text { Total } & 13,617 & \text { Total } & 4,970\end{array}$

\subsection{The Target Countries ASEAN Students Choose for Studying Abroad}

The number of international students and scholars studying and working in a culture beyond their own has significantly increased in past few years (Bista, 2012). In some countries, universities generate substantial incomes from foreign students (Wilkinson et al., 2008).

Based on the study about the most desired countries, students in Singapore, the Philippines, and Indonesia are the most interested in Australia, followed by the UK, which students in Brunei and Malaysia give priority in selecting for further study. Next is the US in which students from Thailand and Vietnam are most interested. Thailand is also a target country according to students from Myanmar and Cambodia. Details are shown in Table 3.

Table 3. The top five target countries ASEAN students aiming for studying abroad

\begin{tabular}{|c|c|c|c|c|}
\hline Counties & $\begin{array}{l}\text { Interested countries } \\
\text { (Outbound) }\end{array}$ & Units & $\begin{array}{l}\text { Interested countries } \\
\text { (Inbound) }\end{array}$ & Units \\
\hline \multirow{5}{*}{ Singapore } & \multirow{5}{*}{ na. } & \multirow{5}{*}{ na. } & Australia & 8,759 \\
\hline & & & United Kingdom & 6,774 \\
\hline & & & United States of America & 4,678 \\
\hline & & & Malaysia & 960 \\
\hline & & & Canada & 399 \\
\hline Total & & 48,938 & & 24,135 \\
\hline \multirow{5}{*}{ Malaysia } & Bangladesh & 6,534 & United Kingdom & 15,583 \\
\hline & Indonesia & 5,700 & Australia & 14,967 \\
\hline & China & 4,956 & United States of America & 7,858 \\
\hline & Nigeria & 4,943 & Egypt & 5,067 \\
\hline & Iran & 3,293 & Jordan & 3,071 \\
\hline Total & & 60,244 & & 64,480 \\
\hline \multirow{5}{*}{ Thailand } & China & 4,544 & United States of America & 7,052 \\
\hline & Myanmar & 1,620 & United Kingdom & 6,246 \\
\hline & Cambodia & 1,182 & Australia & 4,751 \\
\hline & Laos & 793 & Japan & 2,256 \\
\hline & Vietnam & 748 & Egypt & 1,958 \\
\hline Total & & 12,274 & & 28,339 \\
\hline \multirow{5}{*}{ Vietnam } & Laos & 1,772 & United States of America & 19,336 \\
\hline & Cambodia & 381 & Australia & 13,147 \\
\hline & China & 281 & Japan & 6,071 \\
\hline & South Korea & 276 & France & 5,284 \\
\hline & Mongolia & 33 & United Kingdom & 4,236 \\
\hline Total & & 2,874 & & 63,703 \\
\hline \multirow{5}{*}{ Philippines } & \multirow{5}{*}{ na. } & \multirow{5}{*}{ na. } & Australia & 4,432 \\
\hline & & & United States of America & 3,037 \\
\hline & & & New Zealand & 1,105 \\
\hline & & & United Kingdom & 698 \\
\hline & & & Saudi Arabia & 693 \\
\hline Total & & & & 14,696 \\
\hline
\end{tabular}




\begin{tabular}{|c|c|c|c|c|}
\hline Counties & $\begin{array}{l}\text { Interested countries } \\
\text { (Outbound) }\end{array}$ & Units & $\begin{array}{c}\text { Interested countries } \\
\text { (Inbound) }\end{array}$ & Units \\
\hline \multirow{5}{*}{ Indonesia } & \multirow{5}{*}{ na. } & \multirow{5}{*}{ na. } & Australia & 10,168 \\
\hline & & & United States of America & 8,922 \\
\hline & & & Malaysia & 5,700 \\
\hline & & & Japan & 2,387 \\
\hline & & & Egypt & 2,262 \\
\hline Total & & & & 41,919 \\
\hline \multirow{5}{*}{ Myanmar } & \multirow{5}{*}{ na. } & \multirow{5}{*}{ na. } & Thailand & 1,620 \\
\hline & & & United States of America & 1,209 \\
\hline & & & Japan & 1,193 \\
\hline & & & Australia & 775 \\
\hline & & & Russia & 511 \\
\hline Total & & & & 7,450 \\
\hline \multirow{5}{*}{ Laos } & Vietnam & 167 & Vietnam & 1,772 \\
\hline & China & 91 & Thailand & 793 \\
\hline & South Korea & 28 & Australia & 207 \\
\hline & Cambodia & 17 & Japan & 203 \\
\hline & Japan & 10 & France & 69 \\
\hline Total & & 315 & & 3,460 \\
\hline \multirow{5}{*}{ Cambodia } & \multirow{5}{*}{ na } & \multirow{5}{*}{ na } & Thailand & 1,182 \\
\hline & & & Australia & 784 \\
\hline & & & France & 611 \\
\hline & & & United States of America & 527 \\
\hline & & & Vietnam & 381 \\
\hline Total & & & & 5,275 \\
\hline \multirow{5}{*}{ Brunei } & Malaysia & 129 & United Kingdom & 1,932 \\
\hline & Indonesia & 59 & Malaysia & 548 \\
\hline & Pakistan & 27 & Australia & 477 \\
\hline & Bangladesh & 26 & Egypt & 124 \\
\hline & Thailand & 26 & Saudi Arabia & 87 \\
\hline Total & & 529 & & 3,488 \\
\hline
\end{tabular}

\subsection{Factors Affecting the Selection of Higher Education Institutions of Thailand}

The related issues of factors affecting the selection of higher education institutions in Thailand were combined from research results, articles, and academic journals. Thus, the factors used in the study are based on the IPO model. There are 42 factors used in the study, of which are 19 issues have four inputs, 17 issues of seven processes, and six issues of two outputs. Details are shown in Table 4.

Table 4. The factors examined in this study

\begin{tabular}{lll}
\hline & Factors & References \\
\hline Input factor & & \\
\hline & Qualification and teaching experience & (Maclorin, 2011) \\
& Research experience & $\begin{array}{l}\text { (Maclorin, 2011; Saengawut, Srungboonmee, \& } \\
\text { (Saengawnit, 2016) }\end{array}$ \\
& Reliability and reputation 2016) \\
Lecturer & Academic position in university & (Department of International Trade Promotion, \\
& Portion of Thai professors and international professors & 2014) \\
& $\begin{array}{l}\text { Lecturer advice } \\
\text { Academic quality and worldwide } \\
\text { recognition }\end{array}$ & (Pachaneebon, 2014) \\
\hline
\end{tabular}




\begin{tabular}{|c|c|c|}
\hline & Factors & References \\
\hline \multirow{5}{*}{ Institution } & Academic Ranking of World Universities & $\begin{array}{l}\text { (Hobsons EMEA, 2014; Intawa \& Sutamaung, } \\
\text { 2013; Maclorin, 2011; Saengawut et al., 2016; } \\
\text { Waichalad \& To-im, 2016) }\end{array}$ \\
\hline & Image and Prestige of the university & (Intawa \& Sutamaung, 2013; Maclorin, 2011) \\
\hline & Location of country & (Pachaneebon, 2014) \\
\hline & $\begin{array}{l}\text { Facilities that support foreign student e.g. (Dome, SSU } \\
\text { shutter bus) }\end{array}$ & $\begin{array}{l}\text { (Department of International Trade Promotion, } \\
\text { 2014) }\end{array}$ \\
\hline & Facility, location, atmosphere that support education & (Wattanasiri, 2010) \\
\hline \multirow{6}{*}{ Curriculum } & Diversities of subjects and courses in university & \\
\hline & Clear a course description & $\begin{array}{l}\text { (Intawa \& Sutamaung, 2013; Maclorin, 2011; } \\
\text { Pratcharacharoenpong, 2011) }\end{array}$ \\
\hline & Be able to transfer credits between universities & $\begin{array}{l}\text { (Department of International Trade Promotion, } \\
\text { 2014; Pratcharacharoenpong, 2011) }\end{array}$ \\
\hline & Up-to-date course content & (Saengawut et al., 2016) \\
\hline & Future employment prospects after graduation & (Wattanasiri, 2010) \\
\hline & $\begin{array}{l}\text { An opportunity to participate in the dual and } \\
\text { exchange degree programs }\end{array}$ & \\
\hline \multirow{3}{*}{ Cost } & Reasonable tuition fee & $\begin{array}{l}\text { (Maclorin, 2011; Pachaneebon, 2014; } \\
\text { Pratcharacharoenpong, 2011) }\end{array}$ \\
\hline & Study abroad scholarships & \\
\hline & Cost of living to study abroad & $\begin{array}{l}\text { (Department of International Trade Promotion, } \\
\text { 2014) }\end{array}$ \\
\hline \multirow{3}{*}{$\begin{array}{l}\text { Learning } \\
\text { processes }\end{array}$} & $\begin{array}{l}\text { Up-to-date and relevant learning process encouraging } \\
\text { collaborative learning }\end{array}$ & $\begin{array}{l}\text { (Mavondo, Tsarenko, \& } \\
\text { Pratcharacharoenpong, 2011) }\end{array}$ \\
\hline & International academic field trips & \\
\hline & $\begin{array}{l}\text { Corporate academic partnerships between academic } \\
\text { and industry Online course and/or distance learning }\end{array}$ & (Wattanasiri, 2010) \\
\hline \multirow{2}{*}{$\begin{array}{l}\text { Information } \\
\text { and } \\
\text { Marketing }\end{array}$} & Academic advertisement & $\begin{array}{l}\text { (Intawa \& Sutamaung, 2013; Pachaneebon, } \\
\text { 2014) }\end{array}$ \\
\hline & $\begin{array}{l}\text { Course descriptions and information clearly explained } \\
\text { on media (website, facebook, youtube) with various } \\
\text { languages }\end{array}$ & $\begin{array}{l}\text { (Boonchutima, 2010; Chipasit, 2008; } \\
\text { Pratcharacharoenpong, 2011; Waichalad \& } \\
\text { To-im, 2016) }\end{array}$ \\
\hline \multirow{2}{*}{$\begin{array}{l}\text { Cultural } \\
\text { aspect }\end{array}$} & Learn about my own cultural roots & (Hobsons EMEA, 2014) \\
\hline & Learn to live in cultural diversity & (Lewis, 2016; Miller-Perrin \& Thompson, 2014) \\
\hline $\begin{array}{l}\text { Connection } \\
\text { and } \\
\text { Interaction }\end{array}$ & $\begin{array}{l}\text { Social networking with friends from worldwide } \\
\text { perception of the country }\end{array}$ & (Lewis, 2016) \\
\hline Service & Educational services for foreign students & (Pachaneebon, 2014) \\
\hline \multirow{2}{*}{$\begin{array}{l}\text { Politic and } \\
\text { Security }\end{array}$} & Safety on university within and around the university & $\begin{array}{l}\text { (Hobsons EMEA, 2014; Pratcharacharoenpong, } \\
\text { 2011) }\end{array}$ \\
\hline & Political stability & (Hobsons EMEA, 2014) \\
\hline \multirow{2}{*}{$\begin{array}{l}\text { Laws and } \\
\text { Regulation }\end{array}$} & Immigration policy & (Hobsons EMEA, 2014) \\
\hline & Easy to apply visa & \\
\hline $\begin{array}{l}\text { Academic } \\
\text { Quality }\end{array}$ & International publication & (Wattanasiri, 2010) \\
\hline Opportunity & Opportunity in external higher education abroad & $\begin{array}{l}\text { (Hobsons EMEA, 2014; Pratcharacharoenpong, } \\
\text { 2011) }\end{array}$ \\
\hline Future & Opportunity to get employment in destination country & (Wattanasiri, 2010) \\
\hline Employment & Fulfill major requirements/ Personal fulfillment & (Lewis, 2016) \\
\hline
\end{tabular}

From literature reviews, all related factors were summarized in Table 4. From Table 4, the research framework of this study can be displayed in Figure 1. 


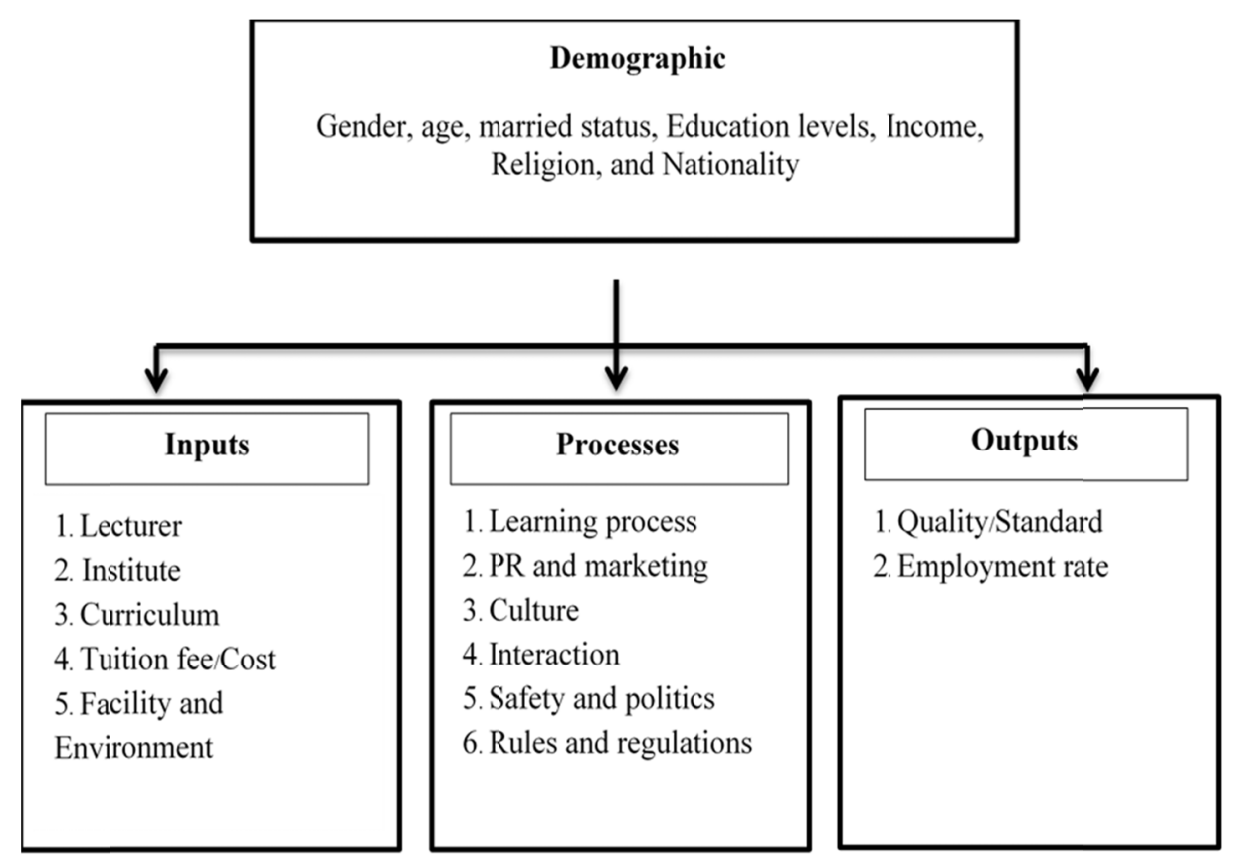

Figure 1. Research framework

\section{Method}

To understand the factor influencing ASEAN and International Students of Higher Education Programs in Thailand. Quantitative and qualitative methods were applied in this study.

\subsection{Sampling and Population}

In the sampling, the sample size was based on continents of international students studying at higher education institutions in Thailand (public and private universities) using a quota sampling method.Once the sample size is reached, the quota sampling is performed according to the continents in order to collect a number of samples from international students from that continent as shown in Table 5.

Table 5. Student sample size from each continent

\begin{tabular}{ccc}
\hline Continental & Units of international student (Persons) & Units of population (Persons) \\
\hline America & 491 & 14 \\
Europe & 697 & 20 \\
Asia (not including ASEAN) & 7,029 & 201 \\
Africa & 391 & 11 \\
ASEAN & 4,896 & 140 \\
Australia and Oceania & 113 & 3 \\
\hline Total & 13,617 & 389 \\
\hline
\end{tabular}

After creating and developing tools used in research, the study was conducted, and a questionnaire was used according to the IPO model. The research team studied the quality of the tools used in the investigation. The tools were tested for accuracy by consulting with five experts and advisors in related fields. It was found that the IOC value was higher than 0.5 for all items. In addition to the data collected from the questionnaire, the researchers conducted in-depth interviews by specifying the target group and key informants by interviewing those responsible for higher education institutions of international students and/or those involved using purposive sampling and snowball sampling as follows: (1) the Office of Higher Education Commission, (2) the Office for National Education Standards and Quality Assessment, (3) the Graduate School, Chulalongkorn University, (4) International College of National Institute of Development Administration, and (5) Thailand International Cooperation Agency, Ministry of Foreign Affairs, by using structured interviews.

\subsection{Data Analysis}

Descriptive statistics were analyzed using frequency and percentage to present the general characteristic of the samples including gender, age, hometown, housing, educational funding source, and average. Then, the 
hypothesis test was presented based on the conceptual framework. In addition, an analysis of basic inferential statistics such as mean and variance was conducted. The Likert scale was used to determine the level of factors and comparison of differences between groups was conducted using the independent sample T-test, one-way ANOVA, and Multiple Comparisons-Tukey's HSD at 0.05 significance level. The factors that were analyzed included demographic factors and dependent variables to determine demographic factors, input factors, processes, and outputs that affect the dependent variables. In addition, the results of in-depth interviews were used in the content analysis to synthesize and analyze data in a reliable manner according to the researcher's issues.

Descriptive statistics were analyzed using frequency and percentage to present the general characteristic of the samples including gender, age, hometown, housing, educational funding source, and average. Then, the hypothesis test was presented based on the conceptual framework. In addition, an analysis of basic inferential statistics such as mean and variance was conducted. The Likert scale was used to determine the level of factors and comparison of differences between groups was conducted using the independent sample T-test, one-way ANOVA, and Multiple Comparisons-Tukey's HSD at 0.05 significance level. The factors that were analyzed included demographic factors and dependent variables to determine demographic factors, input factors, processes, and outputs that affect the dependent variables. In addition, the results of in-depth interviews were used in the content analysis to synthesize and analyze data in a reliable manner according to the researcher's issues.

\section{Results}

From the data collection using questionnaires from random sampling, the sample size was based on continents of international students studying in Thailand's higher education institutions using a quota sampling method. After obtaining the sample size, quota sampling according to continents selected 389 people from a total of 406 people as described in Table 6.

Table 6. Demographics of respondents

\begin{tabular}{cccc}
\hline Factor & Description & Units & Percent \\
\hline \multirow{2}{*}{ Gender } & Male & 227 & 55.90 \\
& Female & 179 & 44.10 \\
& Under 25 & 75 & 18.50 \\
Age & $25-29$ & 161 & 39.70 \\
& $30-39$ & 136 & 33.50 \\
& $40-49$ & 31 & 7.60 \\
& Over 50 & 3 & 0.7 \\
Continents & America & 11 & 2.80 \\
& Europe & 24 & 6.00 \\
& Asia (not including ASEAN) & 156 & 39.10 \\
& Africa & 41 & 10.30 \\
& ASEAN & 163 & 40.90 \\
& Australia and Oceania & 4 & 1.00 \\
& Less than $\$ 25 \mathrm{~K}(£ 15 \mathrm{~K})$ & 179 & 44.90 \\
& $\$ 25 \mathrm{~K}-\$ 50 \mathrm{~K}(£ 15 \mathrm{~K}-£ 31 \mathrm{~K})$ & 120 & 30.10 \\
& $\$ 50 \mathrm{~K}-\$ 75 \mathrm{~K}(£ 31 \mathrm{~K}-£ 46 \mathrm{~K})$ & 52 & 13.00 \\
& $\$ 75 \mathrm{~K}-\$ 100 \mathrm{~K}(£ 46 \mathrm{~K}-£ 61 \mathrm{~K})$ & 11 & 2.80 \\
& $\$ 100 \mathrm{~K}-\$ 150 \mathrm{~K}(£ 61 \mathrm{~K}-£ 92 \mathrm{~K})$ & 18 & 4.50 \\
& Over $\$ 150 \mathrm{~K}(£ 92 \mathrm{~K}+)$ & 19 & 4.80 \\
\hline
\end{tabular}

\subsection{Hypothesis Testing}

The study found that different status, age, continent, income level, education level, religion, and ethnicity of international students influenced the input factors, processes, and outputs that affected the decision to study international programs at the graduate level at different Thailand academic institutions. There were a total of 42 different factors that can be divided into 19 issues of four inputs, 17 issues of seven processes, and six issues of two outputs. The study found that:

The status of different international students influences input factors such as teacher qualification, educational 
institution, and cost budgets, significantly affecting the decision to choose an international course at the graduate level at an academic institution in Thailand at the 0.05 level, but is not significantly different in the process, and output at 0.05 level.

The age range of different international students affects the process in the teaching process issues and the laws and regulations of Thailand significantly affects the decision to study at an international program at the graduate level in academic institutions in Thailand at the 0.05 level, but is not significantly different in input and output factors and at 0.05 level.

Different continents of international students affect the input factor in terms of cost and process in terms of learning about life in various cultures in Thailand, affecting the decision to study at an international program at the graduate level in Thailand significantly different at the 0.05 level, but is not significantly different for the output at the 0.05 level.

The different income level of foreign students has a significant effect on input factor in terms of teachers and academic institutions and the output in terms of career after graduation for the fulfillment of the needs of the individual and career paths that affect the decision to study at an international program at the graduate level at the academic institutions of Thailand significantly different at the 0.05 level, but were not significantly different for the process at the 0.05 level.

The different levels of education of foreign students affect the input in terms of teacher, academic institution, and cost budget, the process in terms of service and facilities for international students, atmosphere, and environment of the country (where the institution is located), and services to international students studying at the academic institutions. The process of teaching and learning at an academic institution in Thailand, marketing and public relations, information on the issue of clear information through online channels, Thailand's laws and regulations regarding difficulties in visas and immigration policies of international students and the output on their ability to perform in their career after graduation, the issue of fulfilling the needs of the individual and career paths that affect the decision to study at an international graduate program at the academic institutions in Thailand are significantly different at the 0.05 level.

Different religions of foreign students influenced the input in terms of curricular activities, academic institution, and cost budget and all factors of the process in this study and the output in terms of quality of education and future careers that affect the decision to study at an international graduate program at the academic institutions in Thailand significantly different at the 0.05 level.

The difference in the ethnicity of foreign students affected input in terms of the academic institutions in Thailand for the quality of the institutions and international recognition (i.e., did the curriculum have a clear explanation and is modern in the current situation). Atmospheric process and environment of the country where the institution is located and the modern teaching, encouragement of the exchange of ideas in the classroom, learning to live in a diverse culture, getting to know new friends, creating a network abroad and internal security and the surrounding areas, academic institution and the output in terms of fulfillment of the needs of the individual and career paths that affect the decision to study at an international graduate program at the academic institutions in Thailand were significantly different at the 0.05 level as shown in Table A1.

In addition, from the classification of factors affecting the selection of an international graduate program at the academic institutions in Thailand by the mean of the answers from the questionnaire, the study indicated that the most important was the teacher with a mean of 4.02 , followed by future career with a mean of 3.87 , followed by interaction and networking abroad with a mean of 3.86. On the other hand, the three least significant factors were the learning process and public relations and marketing with a mean of 3.65 and the lowest was budget with a mean of 3.58. For the minor issues, the educational background and teacher's teaching experience had had the greatest impact with a mean of 4.10 , followed by the teacher's research experience with a mean of 4.04 and the skill enhancement factor and the benefit of a career in the future with a mean of 3.96, respectively. On the other hand, the least decision-making factor is the academic institution/university factor in terms of ranking of institutions worldwide with a mean of 3.52, followed by the budget and ability to find work while studying with a mean of 3.46 and the learning process factor, distance learning, and/or online learning had the least effect on decision making with a mean of 3.33, as shown in Table 7.

Table 7. The average score of international and ASEAN students

\begin{tabular}{ccccccccc}
\hline \multirow{2}{*}{ Factors } & \multicolumn{3}{c}{ International } & \multicolumn{3}{c}{ ASEAN } \\
\cline { 2 - 8 } & Average & SD & Rank & Average & SD & Rank \\
\hline Lecturer & 4.12 & 0.84 & 1 & 4.02 & 0.83 & 1 \\
\hline
\end{tabular}




\begin{tabular}{ccccccc}
\hline Institute/University & 3.85 & 0.88 & 7 & 3.79 & 0.82 & 6 \\
Curriculum & 3.88 & 0.88 & 5 & 3.78 & 0.88 & 7 \\
Budget & 3.66 & 1.01 & 12 & 3.58 & 0.98 & 13 \\
Service and facility Convenient & 3.73 & 0.95 & 10 & 3.68 & 0.90 & 10 \\
Learning processes & 3.70 & 0.96 & 11 & 3.65 & 0.97 & 11 \\
PR and marketing & 3.65 & 0.96 & 13 & 3.65 & 0.98 & 11 \\
Culture & 3.84 & 0.91 & 8 & 3.73 & 0.91 & 8 \\
Connection and Interaction & 3.97 & 0.90 & 3 & 3.86 & 0.90 & 3 \\
Politics and Safety & 3.98 & 0.90 & 2 & 3.83 & 0.98 & 4 \\
Laws and Regulation & 3.79 & 0.96 & 9 & 3.71 & 0.88 & 9 \\
Academic Quality & 3.88 & 0.84 & 5 & 3.83 & 0.78 & 4 \\
Future Employment & 3.91 & 0.87 & 4 & 3.87 & 0.78 & 2 \\
\hline
\end{tabular}

\subsection{Development of Thailand to be a Regional Education Hub}

Deputy Education Minister General Surachet Chaiwong said that the decision to set up the ASEAN Coordinating Center for Education had been made at the recent meeting of the Ministry of Education's Committee to Prepare for the ASEAN Community and Operations After 2015. The project to develop Thailand as the regional education hub aims to attract international students and improve the quality of education management to international standards. It will also prepare for the educational liberalization policy and for accommodating more international students (Office of the Prime Minister, 2015).

In-depth interviews with key informants, focusing on the development of Thailand as a regional education hub, was the subject of government policy 20 years ago during the administration of Prime Minister Thaksin Shinawatra, starting with the promotion of the internationalization of higher education institutions. The Ministry of Education, via the Office of Higher Education Commission (OHEC), has cooperated to develop the curriculum, joint courses or two-degree programs with international institutions and promoting teacher exchange and students. In addition to such issues, the Office of the National Economic and Social Development Board tried to promote such matters but the agency had no direct authority to develop this issue and in 1990, the World Trade Organization (WTO) classified educational services as a product and service, thus there was worldwide promotion of the opening of the global education market. Thailand was one of the countries that had the concept of business development in line with the world. A meeting was held between the institutions of Thailand on the issue "Should educational business be liberalized or barred?" The meeting outcome suggested that educational business should be barred because Thai academic institutions were not ready and they were afraid that they could not compete with foreign institutions. The resolution was not in favor of opening the market in this business (Office of Nation Education Standards and Quality Assessment (Public Organization), 2017). For this reason, the development of Thailand as a regional education hub was unsuccessful and not according to the policy guidelines set by the government.

Thailand's ability to develop into a regional education hub, at present, with 10 ASEAN member countries (note that the Democratic Republic of Timor-Leste is not yet certified as a member country) is under discussion and when the meetings were held, the country always attended. Considering the structure of the education system of each country, it is found that Myanmar and the Philippines have a different education system compared to that of the other member countries. Due to this reason, students from these countries have limited access to higher education institutions in member countries such as Thailand. Moreover, from the ranking of universities by international institutions, Thailand has the capability to compete with the member countries. The countries with a better ranking of quality of education than Thailand are Singapore and Malaysia. If you look at this issue, Thailand has the capacity to develop into a regional education hub because even though Singapore has quality education and is more well-known than Thailand, Singapore has limited space for the number of students it can accept and educational qualifications. For example, institutions from the US promote the teaching in Singapore but they are not accredited by government agencies. This is a risk that foreign students must consider when making their own choices.

Additionally, Singapore's private academic institutions are not accredited by the state. The degrees are certified by the quality of the institution. Their supporting budget for that issue is higher than Thailand's budget. The country's regulations or institutions facilitate the recruitment of potential instructors from leading institutions to become regular teachers in each institution. However, with space constraints and a variety of knowledge that may not meet the needs of developing countries, it is a risk for international students. As a result, there is a limit 
to the development to become a regional education hub in the ASEAN region. A country that has had the capacity to develop as an education hub close to Thailand is Malaysia. It is a country with few restrictions and the quality of education is currently better than Thailand. There are more academic institutions in Malaysia than in Thailand. Curricula are in English and teachers can teach in English like Singapore, but the quality of education in Malaysia may be poorer. Their culture and religion may also be a limiting factor in the development of such matters.

In this regard, the development of Thailand's competitiveness and potential for development as an education hub in ASEAN is also possible. Thailand has the knowledge that is needed to enhance developing countries, in particular, for neighboring countries such as Laos, Myanmar, Cambodia, and Vietnam. Thailand has developed a knowledge base with high potential. It is recognized internationally for agriculture, public health, and education. The academic institutions of the countries teaching these courses are well-respected internationally as well.

Thus, the development of Thailand as a regional education hub in the ASEAN region, should focus on its strengths such as developing an agriculture education hub or a public health education hub. The operation will be set up as a separate educational hub from the academic institutions of Thailand. This makes it easier to make decisions and have access to science and knowledge in such matters. A good example is the Institute of Dermatology, a successful collaboration between Thailand and Japan. At present, Thailand's educational institutions have adapted to such issues. The institutions are collaborating with the Thailand International Cooperation Agency to set up graduate programs according to its framework. In addition, Thai academic institutions are also in need of adjustment. For example, Chulalongkorn University is trying to adjust its curriculum into English. Currently, Chulalongkorn University does not have an international college. However, there are international programs in each team, while other leading universities in Thailand such as Mahidol University, Thammasat University, and the National Institute of Development Administration have adapted to facilitate the study of foreign students. In addition, the private academic institutions of Thailand are developing their competitiveness and accepting more international students.

A description of the advantages and developmental constraints based on the interviews with five related agencies are described in Table 8.

Table 8. Strengths and weaknesses towards the development of an educational hub in ASEAN

\begin{tabular}{|c|c|c|}
\hline & Strengths & Weaknesses \\
\hline Singapore & $\begin{array}{l}\text { 1. Quality of education that is internationally recognition } \\
\text { 2. Small number of institutes thus easy to control the } \\
\text { quality and research grants } \\
\text { 3. Strong interaction between industrial sectors and } \\
\text { education institutes } \\
\text { 4. Strong support from government policy } \\
\text { 5.Government provides enough budget e.g. budget for } \\
\text { recruiting well-known professors, research grants } \\
\text { 6. Support world-class institutes/universities to open in } \\
\text { the country } \\
\text { 7. English courses } \\
\text { 8. Not too many institutes/universities thus the quality } \\
\text { can be controlled } \\
\text { 9. University branches located in other regions } \\
\text { 10. Many scholarships provided for international } \\
\text { students }\end{array}$ & $\begin{array}{l}\text { 1. No quality assurance system } \\
\text { 2. No very strong quality assurance in } \\
\text { comparison to quality assurance in Thailand } \\
\text { 3. Many courses are provided in business } \\
\text { administration, management which are not } \\
\text { suitable for the knowledge needs for developing } \\
\text { countries } \\
\text { 4. Limited land areas }\end{array}$ \\
\hline Malaysia & $\begin{array}{l}\text { 1. Strong support from government policy } \\
\text { 2. Support world-class institute/university to open in the } \\
\text { country. Also, support institute/university to study } \\
\text { internal context and investment in foreign countries } \\
\text { 3. English courses } \\
\text { 4. Many scholarships provided for international students }\end{array}$ & Not equal quality in all institutes \\
\hline Vietnam & - & $\begin{array}{l}\text { The quality of higher education is less } \\
\text { internationally recognition than that of Thailand. }\end{array}$ \\
\hline Indonesia & - & $\begin{array}{l}\text { The quality of higher education is less } \\
\text { international recognition than that of Thailand }\end{array}$ \\
\hline
\end{tabular}




\begin{tabular}{lll}
\hline & Strengths & Weaknesses \\
\hline Philippines & - & $\begin{array}{l}\text { Educational structure is different from other } \\
\text { countries and less international recognition }\end{array}$ \\
\hline Myanmar & - & $\begin{array}{l}\text { Educational structure is different from other } \\
\text { countries and less international recognition }\end{array}$ \\
\hline
\end{tabular}

In summary, the success factors in the development of a regional education hub are the quality of teachers, researchers and academics. This is consistent with the quantitative results collected by the study of international students studying in Thailand. These factors are important and should be emphasized and have continuous development. This is followed by knowledge, education quality, and scholarship. The topic where Thailand has the potential to compete are agriculture, tropical medicine, and food security since developing countries pay attention to these issues. On the other hand, the least effective factor is cooperative project and development. From all the factors that have been collected from interviews with relevant agencies, the most significant factor for promoting and developing a regional education hub in ASEAN, focuses on the development of and expansion of international cooperation in the future.

\section{Discussion}

There were 13,617 international students studying in international programs in Thailand in 2016, with the largest number from Asian countries that are not ASEAN for 7,006 students, accounting for $51.45 \%$, followed by ASEAN countries at 4,896 students or 37\%, and 697 students from European countries or $5.12 \%$. In contrast, countries with the lowest number of international students studying in Thailand is Australia with 52 students or $0.38 \%$. The highest numbers of students from ASEAN countries studying in the international programs in Thailand in 2013-2015 were from Myanmar, Cambodia, and Laos, respectively. On the other hand, the two lowest numbers of students were from Singapore and Brunei. The academic institutions in Thailand have the potential to accommodate and be desired by international students. Most of the institutions are state-managed teaching a wide range of subjects. In addition, it was found that, in particular, Thailand has the potential to compete in is the science of agriculture, tropical medicine, and food security.

The study of the factors affecting the selection of international programs at the graduate level in academic institutions in Thailand found that teacher choice affects the decision of international students and ASEAN students, but the next rank is different for students in two groups. International students place an emphasis on politics and security, while ASEAN students focus on future career prospects after graduation. On the other hand, the two least important factors for both groups of students are the budget for further study in Thailand. This may be due to the fact that the cost of living and tuition fees in Thailand are not high for international students, but they may be high compared to neighboring countries such as Myanmar, Laos, and Cambodia. However, the reason for this is not very significant for the decision to choose Thailand as a target country for graduate study because culture and living life are similar to their original environment so it is easy to adjust. Some students are also supported by the Thai government.

The study found that the status, age, continent, income level, education level, religion, and ethnicity of different international students influenced input, process, and output factors that affect the decision to study in international programs. There are 42 different factors in selecting an international program at the graduate level in academic institutions in Thailand. They are four inputs of 19 issues, seven processes of 17 issues, and two outputs of six issues. The study found that different status, age, continent, income level, education level, religion, and ethnicity of international students have an impact on the input in terms of teachers, education background, teaching experience, and research, institution in terms of location, climate, and environment of the institution, modern teaching process, and discussion encouragement, the culture in terms of learning a variety of cultures, laws and regulations on immigration of foreign students, the fulfillment of the needs of the individual and the career has influenced the decision to study in the international program significantly at the 0.05 level. On the other hand, the factors that are not significantly different at the 0.05 level were the academic institutions in Thailand, proportion of Thai teachers versus foreign teachers, and the quality ranking of the institutions, instructional curriculum, ability to transfer credits between institutions, instructional process, cooperation between institutions and enterprises and distance education and/or online learning, the quality of education, the opportunity to study in higher education institutions, and opportunities to work abroad.

The results from in-depth interviews found that countries with competitive potential as educational centers in ASEAN are Singapore and Malaysia but both countries have the same development constraints as Thailand. It found that Singapore has restrictions on the qualifications of educational institutions in the country and the 
quality of the assurance of education is not rigorous. Knowledge is not very diversified and many courses that focus on business and management do not meet the needs of developing countries. Most importantly, the space is limited and the ability to handle students is not enough to meet the needs. While in Malaysia there is a limit to the quality of education of academic institutions that are not good for all institutions. This is an important limitation. The development of Thailand's competitiveness and potential for development as an education hub in ASEAN is possible. Thailand has the knowledge that is needed for the development of developing countries. It is recognized internationally for agriculture, public health, and education. The educational institutions of the countries that are taught in these courses are well-respected internationally. There is a need to develop a specialized education hub or the education and knowledge hub that Thailand is highly competitive (Excellent Education Hub) and to adjust curriculum to be more international.

\section{References}

Academic Ranking of World Universities. ( 2016). Academic ranking of world universities 2016. Retrieved from http://www.shanghairanking.com/ARWU2016.html

Austin, L., \& Shen, L. (2016). Factors influencing Chinese students' decisions to study in the United States. Journal of International Students, 6(3).

Bista, K. (2012). [Review of the book] Who goes where and why: An overview and analysis of global educational mobility by Macready, C. \& Tucker, C.]. Journal of International Students, 2(1).

Boonchutima, S. (2010). Applicants' satisfaction with the international program website in Chulalongkorn university. Journal of Public Relations and Advertising, 3, 1-19.

Bureau of International Cooperation Strategy. (2016). Thailand's higher education strategy in preparation for ASEAN community. Retrieved from http:/www.moe.go.th/moe/th/news/detail.php?NewsID=29058\&Key= hotnews

Chipasit, K. (2008). Factors affecting the international higher education curriculum of 1st university students. RMUTT Globlal Business and Economics Review, 4, 11-20.

Department of International Trade Promotion. (2014). International education services. Retrieved from http://www.ditp.go.th/contents_attach/85967/85967.pdf

Dill, D. D., \& Soo, M. (2005). Academic quality, league tables, and public policy:A cross-national analysis of university ranking systems. Higher Education, 49, 495-533. https://doi.org/10.1007/s10734-004-1746-8

Hobsons EMEA. ( 2014). Beyond the Data: Influencing International Student Decision Making. Retrieved from https://www.hobsons.com/res/Whitepapers/23_Beyond_The_Data_Influencing_International_Student_Deci sion_Making.pdf

Institute of International Education. ( 2016). The world is the new classroom: Non-credit education abroad Retrieved from New York, USA: https://www.iie.org/Research-and-Insights/Publications/The-World-is-theNew-Classroom-Non-Credit-Education-Abroad

Intawa, P., \& Sutamaung, K. (2013). Factors affecting decision to study master degree abroad. Journal of marketind and communication, 1, 265-281.

Kashif, M., \& Cheewakrakokbit, P. (2018). Perceived service quality-loyalty path: A PAKSERV based investigation of international students enrolled in business schools in Thailand. Journal of Marketing for Higher Education, 28(1), 51-65. https://doi.org/10.1080/08841241.2017.1402113

Lewis, W. (2016). Study abroad influencing factors: an investigation of socio-economic status, social, cultural, and personal factors. Ursidae: The Undergraduate Research Journal at the University of Northern Colorado 5(3), 57-73.

Maclorin, H. (2011). Factors influencing selection and attitude of foreign students studied in National Institute of Development Administration. Retrieved from Bangkok: http://202.44.72.18/home/images/pdf/hataire

Mavondo, F. T., Tsarenko, Y., \& Gabbott, M. (2004). International and local student satisfaction: resources and capabilities perspective. Journal of Marketing for Higher Education, 14(1), 41-60. https://doi.org/10.1300/J050v14n01_03

Miller-Perrin, C., \& Thompson, D. (2014). Outcomes of global education: external and internal change associated with study abroad. New Directions for Students Services, 77-89. https://doi.org/10.1002/ss.20093

Ministry of Foreign Affairs. (2014). The ASEAN Community. Retrieved from 
http://www.mfa.go.th/asean/en/organize/62206-The-Birth-of-ASEAN.html

Office of Nation Education Standards and Quality Assessment (Public Organization) (2017). Moving towards educational hub in ASEAN.

Office of the Prime Minister. (2015). Government to Develop Thailand as an ASEAN Education Hub. Retrieved from https://thailand.prd.go.th/ewt_news.php?nid=1976\&filename=index

Pachaneebon, P. (2014). Factors affecting satisfaction of foreign students in Bangkok. Retrieved from https://prezi.com/7jg0oqxdh48w/presentation/

Pinkaeo, K., \& Speece, M. (2008). Country image and expectations toward international programs in business administration among Thai students. Journal of Marketing for Higher Education, 11(2), 61-89. https://doi.org/10.1300/J050v11n02_04

Pratcharacharoenpong, T. (2011). Factors affecting overseas students' decisions on advanced study in the international undergraduate program in Bangkok (Master of Business). Rajamangala University of Technology Thanyaburi, Pathum Thani.

Saengawut, V., Srungboonmee, T., \& Bumrungkit, S. (2016). Desirable characteristics of Bachelor of Economics International Program. Retrieved from Khonkaen: https://econoffice.kku.ac.th/upload/pupload/14702948711469589345Econpaper1.pdf

Shah, A., \& Laino, H. (2005). Marketing a U.S. university to international students: which approach is beststandardization, adaptation, or contingency? An investigation of consumer needs in seven countries. Journal of Marketing for Higher Education, 16(1), 1-24. https://doi.org/10.1300/J050v16n01_01

Shanka, T., Quintal, V., \& Taylor, R. (2005). Factors Influencing International Students' Choice of an Education Destination-A Correspondence Analysis. Journal of Marketing for Higher Education, 15(2), 31-46. https://doi.org/10.1300/J050v15n02_02

UNESCO Institute of Statistics. (2016). Global flow of tertiary-level students. Retrieved from http://uis.unesco.org/en/uis-student-flow.

Waichalad, U., \& To-im, J. (2016). Influencing factors for post-graduation study decision making of graduate students in faculty of environment and resource studies, Mahidol university. Journal of graduate studies Valaya Alongkron Rajabhat University, 10, 165-177.

Wattanasiri, W. (2010). Integrated marketing communicatetions in promoting Thai international higher education in the greater mekhong sub-region (Doctoral). Dhurakij Pundit University, Bangkok.

Wilkinson, J. W., Mahara, A., \& Quester, P. G. (2008). Asian students: Their experiences and perceptions of Australian universities. Journal of Marketing for Higher Education, 7(3), 65-80. https://doi.org/10.1300/J050v07n03_05

\section{Appendix A}

\subsection{Hypothesis Testing}

The study found that different status, age, continent, income level, education level, religion, and ethnicity of international students influenced the input factors, processes, and outputs that affected the decision to study international programs at the graduate level at different Thailand academic institutions. There were a total of 42 different factors that can be divided into 19 issues of four inputs, 17 issues of seven processes, and six issues of two outputs. Table A1 showed the factors influencing the decision of international students to study in Thailand.

Table A1. Factors influencing the decision of international students to study in Thailand

\begin{tabular}{|c|c|c|c|c|c|c|c|c|}
\hline Factor & Issues & Status & Age & Continent & Income & $\begin{array}{c}\text { Education } \\
\text { level }\end{array}$ & Religion & Nationality \\
\hline \multirow{3}{*}{ Lecturer } & $\begin{array}{l}\text { Qualification and teaching } \\
\text { experience }\end{array}$ & 0.002 & & & 0.000 & 0.000 & & \\
\hline & Research experience & 0.003 & & & 0.000 & 0.001 & & \\
\hline & Reliability and reputation & 0.006 & & & & 0.005 & & \\
\hline \multirow[b]{2}{*}{ Institution } & Location of Institution & 0.000 & & & 0.000 & 0.002 & 0.001 & \\
\hline & $\begin{array}{l}\text { Portion of Thai professors } \\
\text { and international professors }\end{array}$ & & & & & & & \\
\hline
\end{tabular}


Academic quality and

Academic Ranking of

World Universities

Image and Prestige of the university

Location of country

Diversities of subjects and courses in university

Clear a course description

0.003

0.003

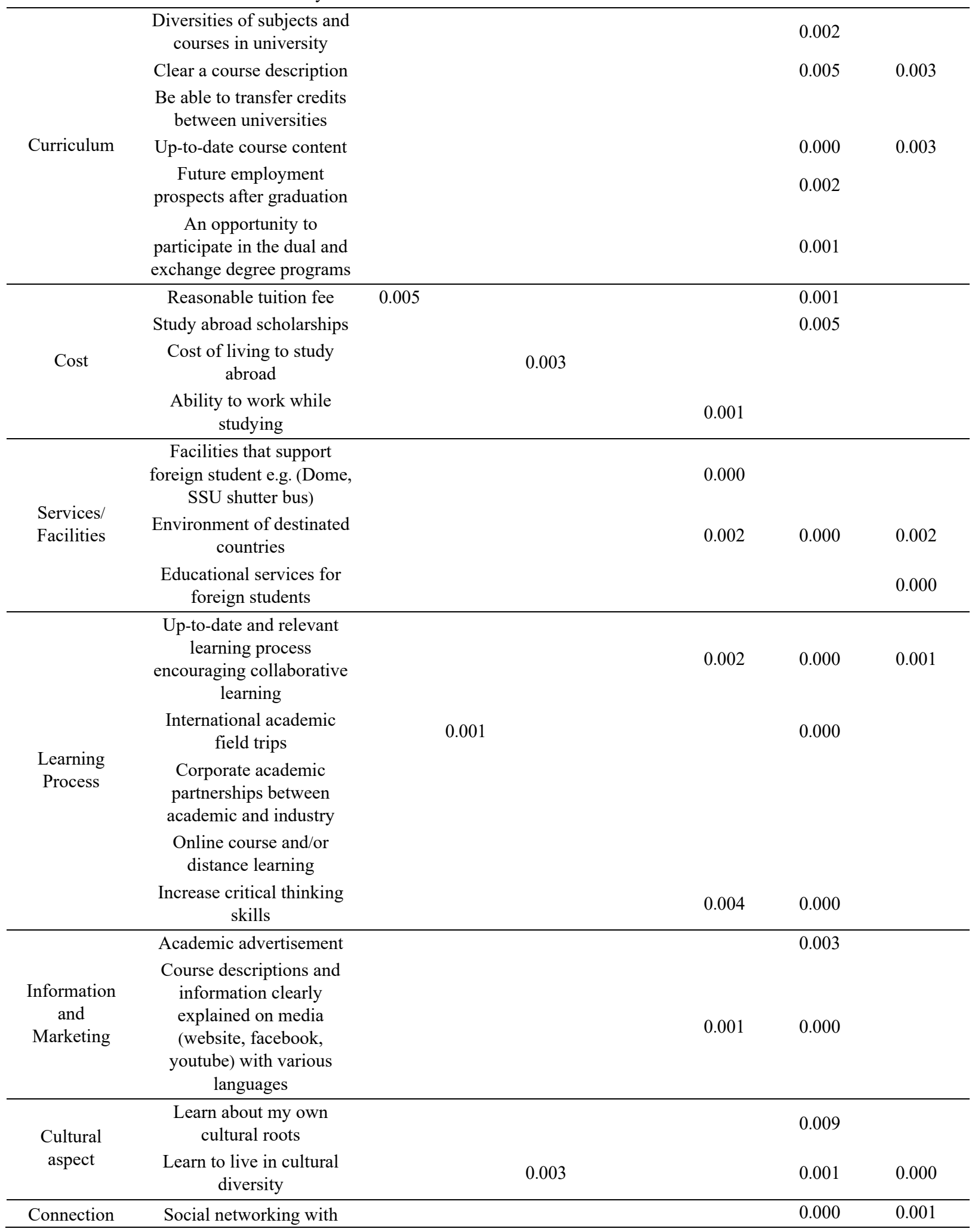




\begin{tabular}{|c|c|c|c|}
\hline $\begin{array}{c}\text { and } \\
\text { Interaction }\end{array}$ & $\begin{array}{l}\text { friends from worldwide } \\
\text { perception of the country }\end{array}$ & & \\
\hline \multirow{2}{*}{$\begin{array}{l}\text { Politic and } \\
\text { Security }\end{array}$} & $\begin{array}{l}\text { Safety on university within } \\
\text { and around the university }\end{array}$ & 0.004 & \multirow[t]{2}{*}{0.000} \\
\hline & Political stability & 0.001 & \\
\hline
\end{tabular}

\section{Copyrights}

Copyright for this article is retained by the author(s), with first publication rights granted to the journal.

This is an open-access article distributed under the terms and conditions of the Creative Commons Attribution license (http://creativecommons.org/licenses/by/4.0/). 